\title{
Rutin accumulation in gardenia calli cultures as a response to phenyl alanine and salicylic acid
}

\author{
Amal Abd El-Latif El-Ashry ${ }^{*}$, Ahmed Mohamed Magdy Gabr, Nermeen Mohamed Arafa and \\ Mohamed Kamal El-Bahr
}

\begin{abstract}
Background: Rutin is one of the flavonoid compounds found in different plant species. Rutin has powerful antioxidant properties. The main target of this study is to elevate rutin content in gardenia (Gardenia jasmonides Ellis) calli cultures. Different concentrations of phenyl alanine $(2,3,4$, and $5 \mathrm{mg} / \mathrm{l})$ were used as a precursor for enhancement of rutin accumulation. Moreover, and to elevate rutin content, salicylic acid (SA) was used at different concentrations (34.5, 69, 103.5, and $138 \mathrm{mg} / \mathrm{l})$. Various biochemical analyses, i.e., determination of total phenols, total flavonoids, and antioxidant activity during three periods, after 2 weeks (the first harvest), after 4 weeks (the second harvest), and after 5 weeks (the third harvest) of culture, were performed. In addition, determination of phenols and flavonoids content by highperformance liquid chromatography (HPLC) were estimated of the three periods.
\end{abstract}

Results: The results showed that the highest value of total phenols ( $9.53 \pm 0.55 \mathrm{mg}$ GAE/g DW of callus) was recorded with $5 \mathrm{mg} / \mathrm{l}$ phenylalanine (PA) at the third harvest. While the highest value of total flavonoids $(0.358 \pm 0.002 \mathrm{mg}$ QE/g DW of callus) was achieved using 2 mg/l P.A. at the third harvest. By using HPLC, it was found that the maximum rutin content was recorded with $3 \mathrm{mg} / \mathrm{l} \mathrm{PA}$ at the third harvest $(429 \mu \mathrm{g} / \mathrm{g}$ DW).

Conclusion: This study showed that rutin and cinnamic acids were the major compounds detected with all treatments and during the three harvest phases of gardenia calli cultures. As well as results declared that the decreasing of cinnamic acid was correlated with the increasing of rutin content, and the maximum rutin content was recorded with applying of $3 \mathrm{mg} / \mathrm{l} \mathrm{PA}$ at the third harvest $(429 \mu \mathrm{g} / \mathrm{g}$ DW).

Keywords: Gardenia, Salicylic acid, Phenyl alanine, Rutin, Calli cultures

\section{Background}

Plants are recognized as a main source of vitamins; it may play a great role in providing medicine and other raw materials. Medicinal plants are the main stone in drug industries around the world. Some chemicals are considered the main responsible for the medicinal value of different plants. Phenolic compounds, alkaloids, tannins, and flavonoids are the most famous compounds of the medicinal plants (Duraipandiyan et al., 2006).

Gardenia jasminoides Ellis is an ornamental and medicinal woody plant that belongs to the family Rubiaceae. It is an evergreen small shrub with white, fragrant flowers.

\footnotetext{
* Correspondence: aaelashry@gmail.com

Department of Plant Biotechnology, Genetic Engineering and Biotechnology Research Division, National Research Centre (NRC), Cairo 12622, Egypt
}

The double-flowered form is used for ornamental purposes, while the single-flowered one is used as a medicinal plant, since the double-flowered form does not bear fruits which is the medicinally used organ (Mizukam, 1989). Gardenia is propagated commercially by grafting or cuttings. It plays an important role in the traditional Chinese medicine (Dharmananda, 2003). It is rich in phenolic compounds and anti-inflammatory flavonoids and it could be used as a treatment for inflammatory diseases or for pain treatment (Uddin et al., 2014). Iridoid glycosides are considered one of the most major components of Gardenia's fruits, which could be converted in color between blue and red. These crocetin derivatives owe coloring properties and water-soluble behavior, opposing the most plant families of carotenoid (Van-Calsteren et al., 1997). 
Biotechnology gives the opportunity to use cells, tissues, organs, or whole organisms by growing them in vitro and genetically manipulate them to get the desired compounds. The callus formed through tissue culture techniques can be used directly to regenerate plantlets, or used as a source of secondary metabolites. Elicitors can be used to enhance the productivity of secondary metabolites in a short period of time (Sathuluri \& Ravishankar, 2000).

Elicitors are foreign molecules often associated with plant pests or diseases. They can attach to special receptor proteins located on plant cell membranes. These receptors are able to recognize the molecular pattern of elicitors and trigger intracellular defense signaling. This response results in the enhancement of metabolites synthesis which reduces damage and increases resistance to pest, disease, or environmental stress (Bektas \& Eulgem, 2015).

The main sources for pharmaceuticals, food additives, flavors, and other industrial materials are plant secondary metabolites. Secondary metabolites accumulation often occurs in plants subjected to stresses including various elicitors. Understanding the pathways of secondary metabolites production through elicitor-induction or precursors addition is important for optimizing their commercial production (Zhao et al., 2005). In this connection, a great progress was made to stimulate secondary metabolites formation and accumulation through plant cell cultures (Rao \& Ravishankar, 2000; Gabr et al., 2017, 2018).

Rutin, which is called also rutoside or vitamin $\mathrm{P}$, has a number of pharmacological effects that has been discovered for it. Buckwheat, most citrus, figs, both black, and green tea, apples, and many other plants possess rutin as one of their active ingredients. Rutin has powerful antioxidant properties. It also helps the human body produce collagen and use vitamin C. In addition, rutin can be used for diet as food supplemented form. Nowadays, rutin has been taking attention for its pharmaceutical effects. It has many pharmacological activities, including antioxidant, anti-carcinogenic, vasoprotective, neuroprotective, and cardioprotective activities (Habtemariam, 2019; Richetti et al., 2011; Javed et al., 2012; Ganeshpurkar \& Saluja, 2017). According to (Rothwell et al. 2015), buckwheat is considered the third main source of rutin among different plants. According to Gabr et al. (2017), Gardenia (Gardenia jasmonides Ellis) may rank the fourth for rutin accumulation.

The current study aimed to elevate rutin accumulation in calli culture of gardenia (Gardenia jasmonides Ellis) which is considered a new source of rutin, by using both phenyl alanine as a phenol precursor and salicylic acid as an elicitor.

\section{Methods}

\section{Plant material}

Gardenia callus was induced and proliferated according to Gabr et al. (2017), by culturing leaves segments excised from in vitro growing gardenia plantlets on MS medium supplemented with $0.5 \mathrm{mg} / \mathrm{l} \mathrm{BA}+0.5 \mathrm{mg} / \mathrm{l} \mathrm{pi-}$ cloram. Leaf-derived callus were subcultured on MS medium supplemented with $4 \mathrm{mg} / \mathrm{l} \mathrm{TDZ}$. Callus obtained were subcultured three times on the same medium for mass callus production.

\section{Effect of phenyl alanine as a phenol precursor on calli cultures}

About $0.5 \mathrm{~g}$ of callus was cultured on:

1. MS medium supplemented with $4 \mathrm{mg} / \mathrm{l} \mathrm{TDZ}$ (control)

2. MS medium supplemented with $4 \mathrm{mg} / \mathrm{l} \mathrm{TDZ}+2$ $\mathrm{mg} / \mathrm{l}$ phenyl alanine

3. MS medium supplemented with $4 \mathrm{mg} / \mathrm{l} \mathrm{TDZ}+3$ $\mathrm{mg} / \mathrm{l}$ phenyl alanine

4. MS medium supplemented with $4 \mathrm{mg} / \mathrm{l} \mathrm{TDZ}+4$ $\mathrm{mg} / \mathrm{l}$ phenyl alanine

5. MS medium supplemented with $4 \mathrm{mg} / \mathrm{l} \mathrm{TDZ}+5$ $\mathrm{mg} / \mathrm{l}$ phenyl alanine

Samples were harvested after 2, 4, and 5 weeks of culturing, the fresh weights were recorded, then dried in oven at $40{ }^{\circ} \mathrm{C}$ for $48 \mathrm{~h}$, and the dry weights were recorded. Dry matter percentage and growth value were calculated according to the following equation:

-Dry matter $(\mathrm{DM})=D_{\mathrm{w}} / F_{\mathrm{w}} \times 100$

Where:

$D_{\mathrm{w}}=$ weight $(\mathrm{g})$ of dry calli at the end of each harvest $F_{\mathrm{w}}=$ weight $(\mathrm{g})$ of fresh calli at the end of each harvest - Growth value $(\mathrm{GV})=P_{t}-P_{0} / P_{0}$

Where:

$P_{t}=$ weight $(\mathrm{g})$ of the fresh callus at the end of each harvest $P_{0}=$ starting weight $(\mathrm{g})$ of the fresh calli

\section{Effect of salicylic acid as elicitor on calli}

About $0.5 \mathrm{~g}$ of callus was cultured on:

1. MS medium supplemented with $4 \mathrm{mg} / \mathrm{l} \mathrm{TDZ}$ (control)

2. MS medium supplemented with $4 \mathrm{mg} / \mathrm{l} \mathrm{TDZ}+0.25$ $\mathrm{mM}(34.5 \mathrm{mg} / \mathrm{l})$ salicylic acid

3. MS medium supplemented with $4 \mathrm{mg} / \mathrm{l} \mathrm{TDZ}+0.50$ $\mathrm{mM}(69 \mathrm{mg} / \mathrm{l})$ salicylic acid

4. MS medium supplemented with $4 \mathrm{mg} / \mathrm{l} \mathrm{TDZ}+0.75$ $\mathrm{mM}(103.5 \mathrm{mg} / \mathrm{l})$ salicylic acid

5. MS medium supplemented with $4 \mathrm{mg} / \mathrm{l} \mathrm{TDZ}+1$ $\mathrm{mM}(138 \mathrm{mg} / \mathrm{l})$ salicylic acid 
Samples were harvested after 2, 4, and 5 weeks of culturing, the fresh weights were recorded, then dried in oven at $40{ }^{\circ} \mathrm{C}$ for $48 \mathrm{~h}$, and the dry weights were recorded. Dry matter percentage and growth value were calculated according to the following equation:

$$
- \text { Dry matter }(\mathrm{DM})=D_{\mathrm{w}} / F_{\mathrm{w}} \times 100
$$

Where:

$D_{\mathrm{w}}=$ weight $(\mathrm{g})$ of dry calli at the end of each harvest $F_{\mathrm{w}}=$ weight $(\mathrm{g})$ of fresh calli at the end of each harvest -Growth value $(\mathrm{GV})=P_{\mathrm{t}}-P_{0} / P_{0}$

Where:

$P_{\mathrm{t}}=$ weight $(\mathrm{g})$ of the fresh callus at the end of each harvest $P_{0}=$ starting weight $(\mathrm{g})$ of the fresh calli

\section{Biochemical analysis}

\section{Sample extraction}

One hundred milligrams of grounded dried samples were extracted with $1.5 \mathrm{ml} 80 \%$ methanol for $24 \mathrm{~h}$. Then, the samples were sonicated in an ultrasonic water bath (Grant, UK) for $20 \mathrm{~min}$. Samples were centrifuged for 5 min at $6000 \mathrm{rpm}$ (Sigma 2-16 PK, Germany). The supernatants were collected, and the pellets were re-extracted twice with $500 \mu \mathrm{l}$ of $80 \%$ methanol. The extracts were stored at $-20{ }^{\circ} \mathrm{C}$ until further use according to Gabr et al. (2017).

\section{Determination of total phenols in calli}

Total phenols were determined by the Folin-Ciocalteu micro-method (Slinkard \& Singleton, 1997; Saeedeh \& Asna, 2007). A $20 \mu \mathrm{l}$ of extract solution was mixed with $1.16 \mathrm{ml}$ of distilled water and $100 \mu \mathrm{l}$ of Folin-Ciocalteu's reagent followed by $300 \mu \mathrm{l}$ of $200 \mathrm{~g} / \mathrm{l} \mathrm{Na}_{2} \mathrm{CO}_{3}$ solution. The mixture was incubated in a water bath at $40{ }^{\circ} \mathrm{C}$ for $30 \mathrm{~min}$ and its absorbance at $760 \mathrm{~nm}$ was measured. A control with no added extract was also analyzed. Gallic acid was used as standard for the calibration curve. Total phenolic content as gallic acid equivalent was calculated using the following equation:

$$
A=0.98 C+9.925 \times 10^{-3}\left(R^{2}=0.9996\right)
$$

Where $A$ is the gallic acid absorbance and $C$ is the concentration.

\section{Determination of total flavonoids}

Total flavonoid content was determined according to the method described by Ordon et al. (2006). Then, $0.5 \mathrm{ml}$ of $20 \mathrm{~g} \mathrm{l}^{-1} \mathrm{AlCl}_{3}$, methanolic solution was added to $0.5 \mathrm{ml}$ of extract solution. After $1 \mathrm{~h}$ at room temperature, the absorbance at $420 \mathrm{~nm}$ was measured. Yellow color shows the presence of flavonoids. A control with no added extract was also analyzed. Total flavonoids content expressed as quercetin equivalent $(\mathrm{QE})$ was calculated using the following equation based on the calibration curve:

$$
Y=0.0255 X\left(R^{2}=0.9812\right)
$$

Where $X$ is the absorbance and $Y$ is the concentration (mg QE g $\left.{ }^{-1} \mathrm{DW}\right)$.

\section{The free radical scavenging capacity of DPPH}

The DPPH assay according to Gabr et al. (Gabr et al., 2017) was used with some modifications. The stock reagent solution $\left(1 \times 10^{-3} \mathrm{~mol} \mathrm{l}^{-1}\right)$ was prepared by dissolving $22 \mathrm{mg}$ of $\mathrm{DPPH}$ in $50 \mathrm{ml}$ of methanol and stored at $-20^{\circ} \mathrm{C}$ until use. The working solution $\left(6 \times 10^{-5} \mathrm{~mol} \mathrm{l}^{-1}\right)$ was prepared by mixing $6 \mathrm{ml}$ of stock solution with $100 \mathrm{ml}$ of methanol to obtain an absorbance value of $0.8 \pm 0.02$ at $515 \mathrm{~nm}$, as measured using a spectrophotometer. Extract of different samples $(0.1 \mathrm{ml}$ of each) were vortexed for $30 \mathrm{~s}$ with $3.9 \mathrm{ml}$ of DPPH solution and left to react for $30 \mathrm{~min}$, after which the absorbance at $515 \mathrm{~nm}$ was recorded. A control with no added extract was also analyzed. Scavenging activity was calculated as follow:

$$
\begin{aligned}
& \text { Radical-scavenging }(\mathrm{DPPH}) \text { activity }(\%) \\
& \quad=\left[\left(A_{\text {control }}-A_{\text {sample }}\right) / A_{\text {control }}\right] \times 100
\end{aligned}
$$

Where $A$ is the absorbance at $515 \mathrm{~nm}$.

\section{Determination of phenols and flavonoids content by HPLC}

The extraction was performed according to Gabr et al. (2017); flavonoids (100 $\mathrm{mg}$ ) were extracted from the dried residue with $2 \mathrm{ml}$ of methanol at $40{ }^{\circ} \mathrm{C}$ for $8 \mathrm{~h}$. The methanol solution was evaporated and concentrated to a dry residue. The extract was dissolved in $1 \mathrm{ml}$ of methanol and kept at $4{ }^{\circ} \mathrm{C}$ in darkness. The content of flavonoids was determined by HPLC on a UNICAM CRYS TAL 200 liquid chromatograph. The mobile phase consisted of methanol and water (both acidified with $0.3 \%$ Ortho-phosphoric acid w/v). Flavonoids were eluted with linear gradient from water to $50 \%$ methanol for $5 \mathrm{~min}$, following by isocratic elution with $50 \%$ methanol for $20 \mathrm{~min}$. The flow rate was $1.4 \mathrm{ml} / \mathrm{min}$. Substances were detected by absorption at $\lambda=288 \mathrm{~nm}$ and their identification were carried out by the comparison of retention times and absorption spectra with standards complex of phenols: chlorogenic acid, vanillic, ferulic, rosmarinic, and cinnamic. For flavonoids standards: rutin (quercetin-3-rutinosid), apeginin-7-glucoside, and Kaempferol (kaempferol-3-rutinoside). Samples' content was expressed as $\mu \mathrm{g} / \mathrm{g}$ dry weight and derived using a known concentration of standard and sample peak areas. 


\section{Statistical analysis}

All analyses were performed in triplicate and data reported as mean \pm standard deviation (SD). Data were subjected to analysis of variance (one-way ANOVA) $(P<0.05)$. Results were processed by Excel (Microsoft Office 2010) and SPSS Version 17.0 (SPSS Inc., Chicago, IL, USA)

\section{Results}

\section{Callus induction and proliferation}

Callus induction was occurred by culturing leaf segments excised from in vitro growing Gardenia plantlets on MS medium supplemented with $0.5 \mathrm{mg} / \mathrm{l} \mathrm{BA}+0.5 \mathrm{mg} / \mathrm{l}$ picloram according to Gabr et al. (2017). Calli were grown successfully on the selected medium (callus induction medium) after 40 days of culture (Fig. 1).

Leaves-derived calli were re-cultured on MS medium containing $4 \mathrm{mg} / \mathrm{l} \mathrm{TDZ}$ according to Gabr et al. (2017); for callus production, leaves calli were proliferated increasingly within two subcultures at 4-week intervals for each subculture (Fig. 2).

\section{Effect of phenyl alanine and salicylic acid on callus growth criteria}

Phenylalanine (PA) at concentrations of 2, 3, 4, and $5 \mathrm{mg} / \mathrm{l}$ and salicylic acid (SA) at concentrations of $0.25,0.5,0.75$, and $1.0 \mathrm{mM} / \mathrm{l}$ which is equivalent to $34.5,69,103.5$, and $138 \mathrm{mg} / \mathrm{l}$ were added to the most favored medium (MS medium $+4 \mathrm{mg} / \mathrm{l}$ TDZ) for calli production as a control to study the impacts of those on these parameters, fresh and dry weights, dry matter, and growth value of calli during three harvested times.

\section{Calli parameters for the first harvest}

Leaves-derived calli were harvested after 2 weeks (first harvest) of culturing on MS medium enriched with different concentrations of either PA or SA; calli growth measurements are presented in Fig. 3. Effect of PA or SA on calli growth parameters showed that MS medium

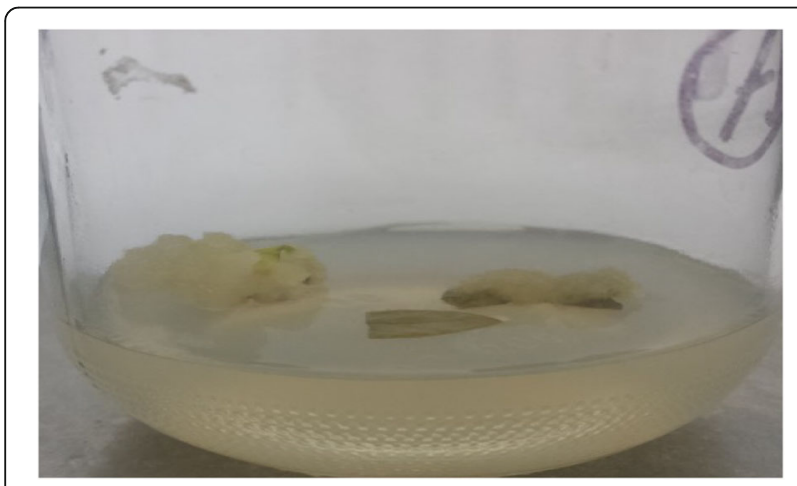

Fig. 1 Induced calli of gardenia leaf explants grown on MS medium containing $0.5 \mathrm{mg} / \mathrm{l} \mathrm{BA}+0.5 \mathrm{mg} /$ I Picloram

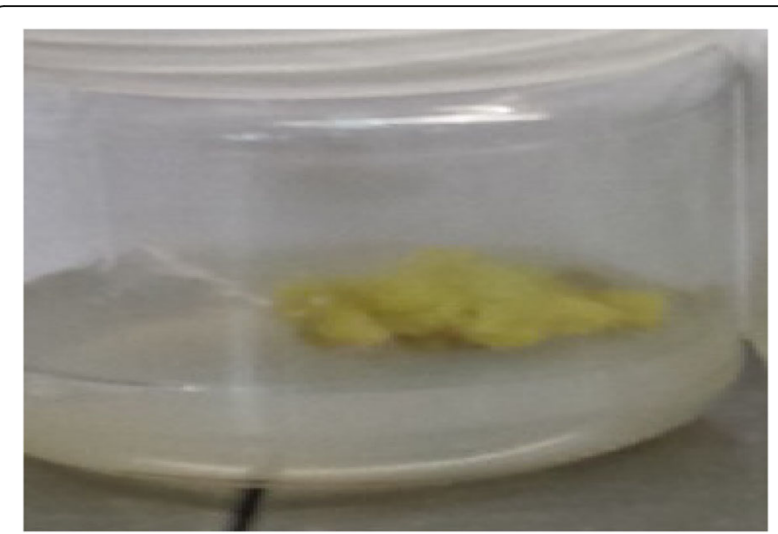

Fig. 2 Gardenia leaf calli produced on MS medium supplemented with $4 \mathrm{mg} / \mathrm{IDZ}$ and incubated under light condition $16 / 8 \mathrm{~h}$ at $26 \pm$ $1{ }^{\circ} \mathrm{C}$ for 4 weeks

supplemented with $138 \mathrm{mg} / \mathrm{l} \mathrm{SA}$ or $2 \mathrm{mg} / \mathrm{l} \mathrm{PA}$ or 103.5 $\mathrm{mg} / \mathrm{l} \mathrm{SA}$ or $5 \mathrm{mg} / \mathrm{l} \mathrm{PA}$ increased callus fresh weight $(6.23 \pm 0.11,5.39 \pm 0.023,5.3 \pm 0.23$, and $5.25 \pm 0.011 \mathrm{~g}$, respectively) compared to the control $(5 \pm 0.17 \mathrm{~g})$. MS culture media supplemented with 138 or 103.5 or $34.5 \mathrm{mg} / \mathrm{l} \mathrm{SA}$ increased callus dry weight $(0.76 \pm$ $0.023,0.74 \pm 0.005$, and $0.68 \pm 0.017$ g, respectively) compared to the control $(0.62 \pm 0.011 \mathrm{~g})$, while MS culture media supplemented with 34.5 or $103.5 \mathrm{mg} / \mathrm{l}$ SA or $3 \mathrm{mg} / \mathrm{l} \mathrm{PA}$ or $138 \mathrm{mg} / \mathrm{l} \mathrm{SA}$ increased calli dry matter $(15.31 \pm 0.008,14 \pm 0.502,12.95 \pm 0.340$, and $12.19 \pm 0.140 \%$, respectively) compared to the control $(12.41 \pm 0.190 \%)$ and MS culture media supplemented with $138 \mathrm{mg} / \mathrm{l} \mathrm{SA}$ or $2 \mathrm{mg} / \mathrm{l} \mathrm{PA}$ or $103.5 \mathrm{mg} / \mathrm{l} \mathrm{SA}$ or $5 \mathrm{mg} / \mathrm{l} \mathrm{PA}$ increased calli growth value (11.46 \pm $0.230,9.78 \pm 0.040,9.6 \pm 0.460$, and $9.5 \pm 0.020$ ) compared to the control $(9 \pm 0.340)$. The abovementioned results manifested that in spite of SA at concentration $138 \mathrm{mg} / \mathrm{l}$ promoted calli growth in terms of its fresh and dry weights and growth value, but $34.5 \mathrm{mg} / \mathrm{l}$ of SA enhanced calli dry matter. Therefore, it is advised to add $34.5 \mathrm{mg} / \mathrm{l} \mathrm{SA}$ to the culture medium for obtaining calli containing maximum value of calli dry matter. Overall, SA which is considered as an elicitor is recommended more than PA as a precursor for calli growth recovery in the first harvest of in vitro culture.

\section{Calli parameters for the second harvest}

Leaves-derived calli were harvested after 4 weeks (second harvest) of culturing on MS medium fortified with different concentrations of PA or SA. Calli growth measurements are presented in Fig. 4. Results showed that MS medium supplemented with 103.5, 34.5, $138 \mathrm{mg} / \mathrm{l}$ SA or $2 \mathrm{mg} / \mathrm{l} \mathrm{PA}$ or $69 \mathrm{mg} / \mathrm{l} \mathrm{SA}$ or 4,3 , and $5 \mathrm{mg} / \mathrm{l} \mathrm{PA}$ decreased both of calli fresh weight $(6.07 \pm 0.569,5.57 \pm$ $0.243,5.23 \pm 0.566,4.78 \pm 0.017,4.62 \pm 0.339,4.44 \pm$ 


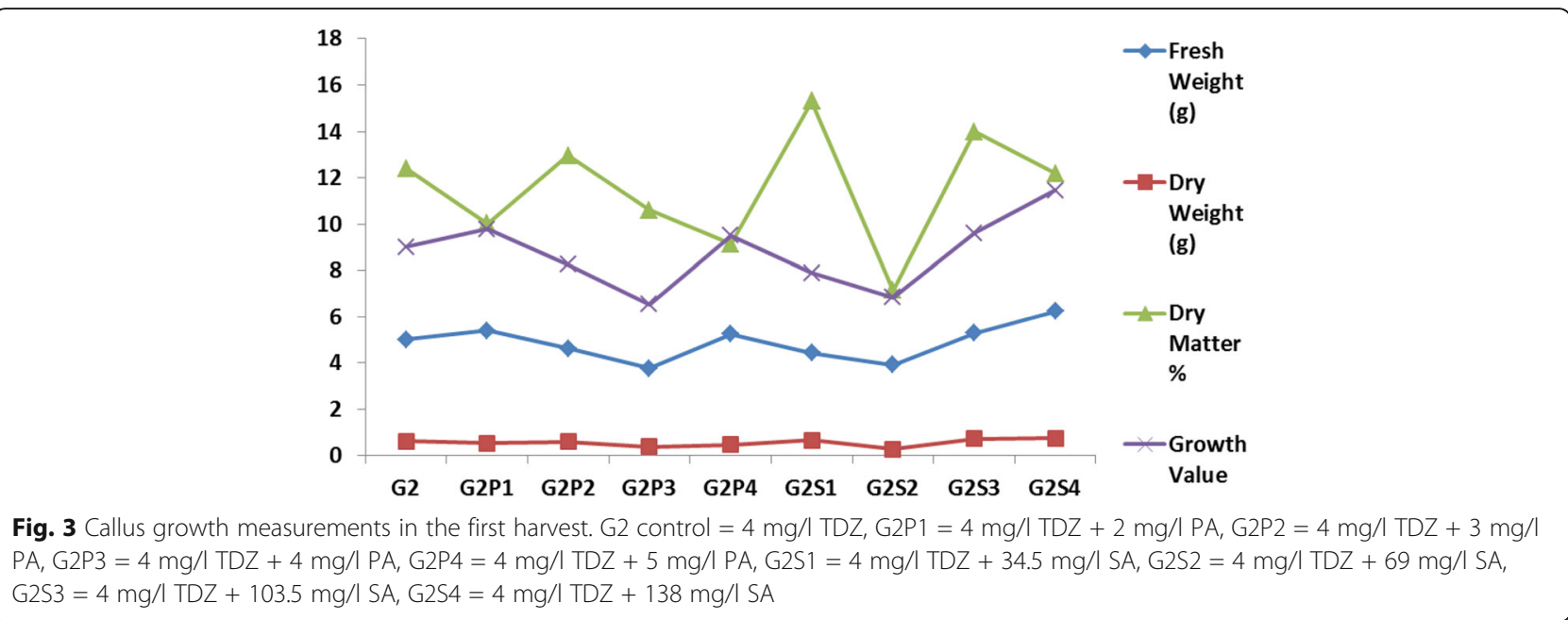

$0.138,4.16 \pm 0.80,3.28 \pm 0.097 \mathrm{~g}$, respectively) and growth value $(11.15 \pm 1.139,10.14 \pm 0.487,9.46 \pm 1.133$, $8.56 \pm 0.034,8.24 \pm 0.678,7.88 \pm 0.277,7.32 \pm 0.161$, and $5.56 \pm 0.194$, respectively) less than the control (6.93 $\pm 0.173 \mathrm{~g}, 12.86 \pm 0.034)$. While, all the treatments of 69, 138, 34.5, and $103.5 \mathrm{mg} / \mathrm{l} \mathrm{SA}$ or $5,3,2$, and $4 \mathrm{mg} / \mathrm{l}$ PA increased significantly the calli dry matter (18.96 \pm $0.993,17.24 \pm 1.136,16.88 \pm 0.437,16.43 \pm 1.605,15.04 \pm$ $0.460,14.89 \pm 0.127,12.96 \pm 0.314$, and $11.9 \pm 0.407 \%$, respectively) more than the control $(8.63 \pm 0.282 \%)$. Taking into account that the positive effect of $103.5,34.5,138$, and $69 \mathrm{mg} / \mathrm{l} \mathrm{SA}$ or 2 and $3 \mathrm{mg} / \mathrm{l} \mathrm{PA}$ on calli dry weight $(0.98 \pm 0.060,0.94 \pm 0.034,0.89 \pm 0.045,0.87 \pm 0.17,0.62$ \pm 0.017 , and $0.62 \pm 0.017 \mathrm{~g}$, respectively) compared to the control $(0.6 \pm 0.034 \mathrm{~g})$ except the treatments of 4 and 5 $\mathrm{mg} / \mathrm{l} \mathrm{PA}$ which recorded the least calli dry weight $(0.53 \pm$ 0.034 and $0.49 \pm 0.017 \mathrm{~g}$, respectively). According to these results, it is recommended to enrich calli culture medium in the second harvest of culturing by either SA or PA with their different concentrations to boost both of calli dry matter and dry weight, particularly using $69 \mathrm{mg} / \mathrm{l}$ of SA.

\section{Calli parameters for the third harvest}

Leaves-derived calli were harvested after 5 weeks (third harvest) of culturing on MS medium enhanced with different concentrations of either PA or SA. It was found that using either PA or SA affected positively calli growth parameters as shown in Fig. 5. Calli fresh weight in the treatments of $34.5,138,103.5$, and $69 \mathrm{mg} / \mathrm{l} \mathrm{SA}$ or $5,4,2$, and $3 \mathrm{mg} / \mathrm{l} \mathrm{PA}$ gave higher values $(12 \pm 1.154,12$ $\pm 1.050,11.16 \pm 0.982,10.56 \pm 0.938,8.96 \pm 0.088,7.94$ $\pm 0.070,5.87 \pm 0.105$, and $5.28 \pm 0.087 \mathrm{~g}$, respectively) than the control $(4.28 \pm 0.557 \mathrm{~g})$. Calli dry weight in the treatments of $103.5,34.5,69$, and $138 \mathrm{mg} / \mathrm{l} \mathrm{SA}$ or $2,3,5$, and $4 \mathrm{mg} / \mathrm{l} \mathrm{PA}$ recorded higher values $(1.09 \pm 0.060$, $1.06 \pm 0.088,1.06 \pm 0.088,1.06 \pm 0.080,0.93 \pm 0.035$, $0.91 \pm 0.041,0.88 \pm 0.020$, and $0.85 \pm 0.012$ g, respectively) than the control $(0.76 \pm 0.017 \mathrm{~g})$. Growth values of

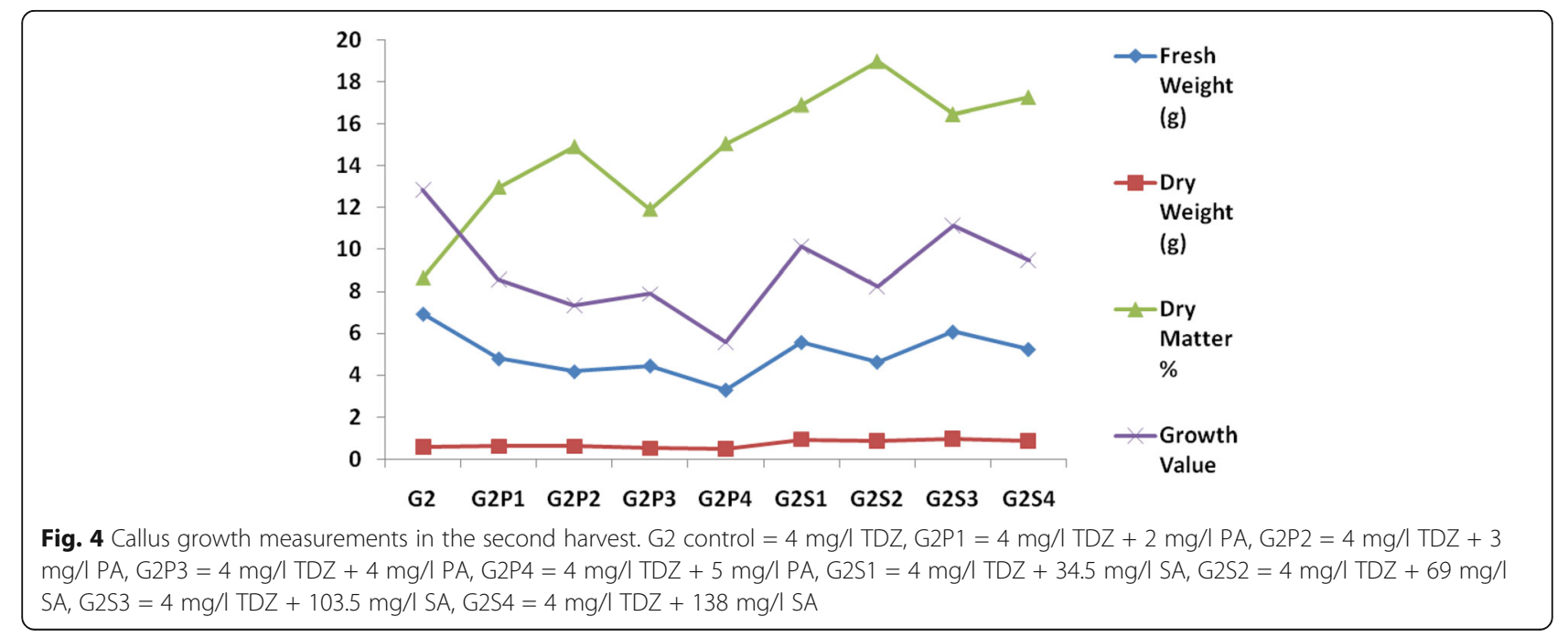




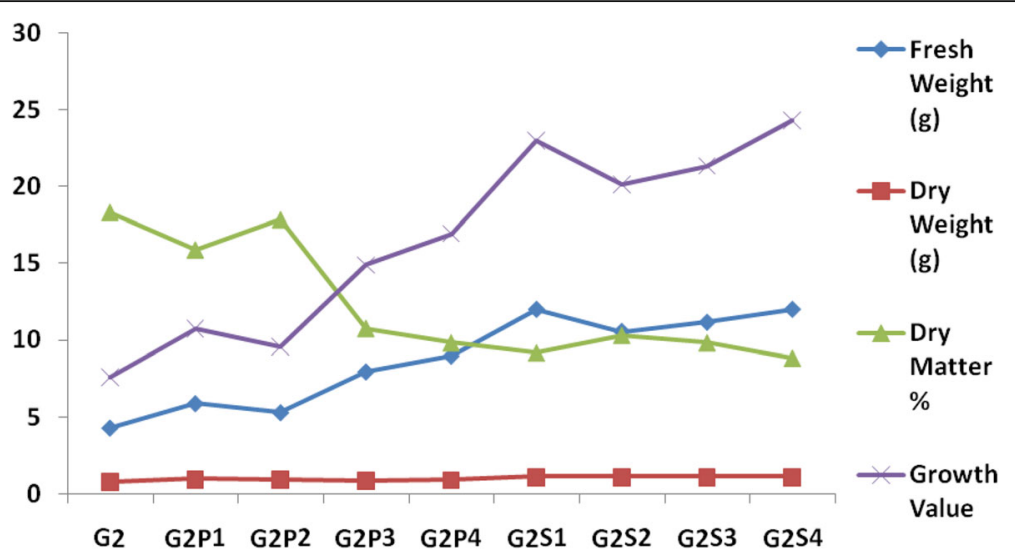

Fig. 5 Callus growth measurements in the third harvest. $\mathrm{G} 2$ control $=4 \mathrm{mg} / \mathrm{IDZ}, \mathrm{G} 2 \mathrm{P} 1=4 \mathrm{mg} / \mathrm{IDZ}+2 \mathrm{mg} / \mathrm{PA}, \mathrm{G} 2 \mathrm{P} 2=4 \mathrm{mg} / \mathrm{l} \mathrm{TDZ}+3 \mathrm{mg} / \mathrm{l}$ $\mathrm{PA}, \mathrm{G} 2 \mathrm{P} 3=4 \mathrm{mg} / \mathrm{ITD}+4 \mathrm{mg} / \mathrm{PA}, \mathrm{G} 2 \mathrm{P} 4=4 \mathrm{mg} / \mathrm{IDZ}+5 \mathrm{mg} / \mathrm{PA}, \mathrm{G} 2 \mathrm{~S} 1=4 \mathrm{mg} / \mathrm{IDZ}+34.5 \mathrm{mg} / \mathrm{l} \mathrm{SA}, \mathrm{G} 2 \mathrm{~S} 2=4 \mathrm{mg} / \mathrm{l} \mathrm{TDZ}+69 \mathrm{mg} / \mathrm{I} \mathrm{SA}$, $\mathrm{G} 2 \mathrm{~S} 3=4 \mathrm{mg} / \mathrm{TDZ}+103.5 \mathrm{mg} / \mathrm{ISA}, \mathrm{G} 2 \mathrm{~S} 4=4 \mathrm{mg} / \mathrm{TDZ}+138 \mathrm{mg} / \mathrm{SA}$

calli in the treatments of $138,34.5,103.5$, and $69 \mathrm{mg} / \mathrm{l}$ SA or $5,4,2$, and $3 \mathrm{mg} / \mathrm{l} \mathrm{PA}$ were $(24.33 \pm 1.804,23 \pm$ $2.309,21.33 \pm 1.964,20.13 \pm 1.877,16.93 \pm 0.176,14.88$ $\pm 0.140,10.74 \pm 0.211$, and $9.56 \pm 1.741$, respectively) more than the control $(7.56 \pm 1.115)$. While, dry matter percent for 3, 2, and $4 \mathrm{mg} / \mathrm{l} \mathrm{PA}$ or 69 and $103.5 \mathrm{mg} / \mathrm{l} \mathrm{SA}$ or $5 \mathrm{mg} / \mathrm{l} \mathrm{PA}$ or 34.5 and $138 \mathrm{mg} / \mathrm{l} \mathrm{SA}$ recorded lower values $(17.85 \pm 1.878,15.89 \pm 0.459,10.78 \pm 0.101,10.33$ $\pm 1.481,9.84 \pm 0.360,9.84 \pm 1.610$, and $9.19 \pm 0.125 \%$, respectively) than the control $(18.32 \pm 2.284 \%)$. From these investigations, it could be concluded that either PA or SA with their different concentrations increased all calli growth parameters except the dry matter percentages. Subsequently, for obtaining high dry matter yield of calli in the third harvest of culturing, it is not recommended to add PA or SA.

\section{Biochemical analysis}

Determination of total phenols in calli cultures

Data in Table 1 presented the average values of total phenols content in calli grown on MS medium supplemented with $2,3,4$, and $5 \mathrm{mg} / \mathrm{l}$ of phenylalanine (PA) or $34.5,69$, 103.5, and $138 \mathrm{mg} / \mathrm{l} \mathrm{SA}$ at three harvested periods. Determination of total phenols content was performed in $\mathrm{mg} / 1$ g calli dry weight using Folin-Ciocalteu reagent and expressed as gallic acid equivalent. Calli subjected to 5 $\mathrm{mg} / \mathrm{l} \mathrm{PA}$ recorded the maximum value of total phenol $(9.53 \pm 0.55)$ in the third harvest followed by 4,3 , and 2 $\mathrm{mg} / \mathrm{l}(9.52 \pm 0.51,9.41 \pm 0.36$, and $7.32 \pm 2.62$, respectively) compared to the control $(5.39 \pm 1.21)$ in the third harvest. By using different P.A. concentrations, it is noticed the gradually increment of phenols content with the increment of PA concentrations. Generally, the addition

Table 1 Total phenols content in gardenia calli cultures cultured on MS media contained different concentrations of phenyl alanine or salicylic acid during the three harvested periods of culturing

\begin{tabular}{|c|c|c|c|}
\hline \multirow[t]{2}{*}{ Treatments } & \multicolumn{3}{|l|}{ Total phenol (mg GAE/ g DW of callus) } \\
\hline & First harvest (after 2 weeks of culturing) & Second harvest (after 4 weeks of culturing) & Third harvest (after 5 weeks of culturing) \\
\hline Control & $1.72 \pm 0.11$ & $6.20 \pm 1.23$ & $5.39 \pm 1.21$ \\
\hline $2 \mathrm{mg} / \mathrm{l}$ phenylalanine & $4.36 \pm 0.32$ & $5.76 \pm 0.04$ & $7.32 \pm 2.96$ \\
\hline $3 \mathrm{mg} / \mathrm{l}$ phenylalanine & $2.03 \pm 0.06$ & $5.98 \pm 0.46$ & $9.41 \pm 0.36$ \\
\hline $4 \mathrm{mg} / \mathrm{l}$ phenylalanine & $2.53 \pm 0.14$ & $5.14 \pm 0.23$ & $9.52 \pm 0.51$ \\
\hline $5 \mathrm{mg} / \mathrm{l}$ phenylalanine & $2.62 \pm 0.04$ & $5.69 \pm 0$ & $9.53 \pm 0.55$ \\
\hline $\begin{array}{l}0.25 \mathrm{mM} \text { salicylic acid } \\
(34.5 \mathrm{mg} / \mathrm{l})\end{array}$ & $2.01 \pm 0.23$ & $1.96 \pm 0.92$ & $4.19 \pm 2.33$ \\
\hline $\begin{array}{l}0.5 \mathrm{mM} \text { salicylic acid } \\
(69 \mathrm{mg} / \mathrm{l})\end{array}$ & $1.19 \pm 0.23$ & $1.56 \pm 0.122$ & $2.16 \pm 0.93$ \\
\hline $\begin{array}{l}0.75 \mathrm{mM} \text { salicylic acid } \\
(103.5 \mathrm{mg} / \mathrm{l})\end{array}$ & $2.03 \pm 1.15$ & $1.47 \pm 0.53$ & $1.52 \pm 1.06$ \\
\hline $\begin{array}{l}1 \mathrm{mM} \text { salicylic acid } \\
(138 \mathrm{mg} / \mathrm{l})\end{array}$ & $1.36 \pm 0.05$ & $1.18 \pm 0.47$ & $1.15 \pm 0.19$ \\
\hline
\end{tabular}

Data represent mean \pm SD 
of PA at the range of 2 to $5 \mathrm{mg} / \mathrm{l}$ enhanced phenols accumulation more than the control at all harvested periods. On the other hand, all the treatments of SA reduced the phenols content lower than the control specially using 138 $\mathrm{mg} / \mathrm{l}(1.15 \pm 0.19)$. Regarding the data in Table 1, it is appeared that there is a negative effect of SA particularly at high concentrations on phenols production. While, using the lowest concentration of SA recorded phenols content value $(4.19 \pm 2.33)$ close to the control $(5.39 \pm 1.21)$ but still lower than the control.

\section{Determination of total flavonoids in calli cultures}

Flavonoids determination in calli cultures grown on MS medium fortified with either PA $(2,3,4$, and $5 \mathrm{mg} / \mathrm{l})$ or SA $(34.5,69,103.5$, and $138 \mathrm{mg} / \mathrm{l})$ were calculated by expression as quercetin equivalent $(\mathrm{QE})$ and the mean values of total flavonoids during the three harvested periods of culturing are shown in Table 2. At the first harvest, the total flavonoids recorded the maximum value when using $69 \mathrm{mg} / \mathrm{l}$ of SA $(0.305 \pm 0.055 \mathrm{mg} / \mathrm{g})$ followed by $34.5 \mathrm{mg} / \mathrm{l}$ of SA with a yield of $(0.232 \pm$ $0.029 \mathrm{mg} / \mathrm{g}$ ). While in the third harvest, the optimal concentration promoting the highest increment in total flavonoids content was with using $2 \mathrm{mg} / \mathrm{l} \mathrm{PA}(0.358 \pm$ $0.002 \mathrm{mg} / \mathrm{g}$ ). In consideration, the obtained intermediate values of total flavonoids content derived from gardenia calli cultures which elicited with both of $5 \mathrm{mg} / \mathrm{l} \mathrm{PA}$ and $138 \mathrm{mg} / \mathrm{l} \mathrm{SA}$ were $0.256 \pm 0.001 \mathrm{mg} / \mathrm{g}$ and $0.277 \pm 0.004$ $\mathrm{mg} / \mathrm{g}$, respectively at the second harvest. The data in Table 2 revealed that MS medium elicited by SA increased the total flavonoids content in gardenia cultures more than MS medium fortified with PA at the first and second harvests of culturing, but using $2 \mathrm{mg} / \mathrm{l} \mathrm{PA}$ gave the highest total flavonoid content at the third harvest of culturing. Then, it could be concluded that to obtain the highest total flavonoids content, it is advisable to add 69 $\mathrm{mg} / \mathrm{l} \mathrm{SA}$ in Gardenia calli culture medium for 2 weeks $(0.305 \pm 0.055 \mathrm{mg} / \mathrm{g})$ or add $2 \mathrm{mg} / \mathrm{l} \mathrm{PA}$ for 5 weeks $(0.358 \pm 0.002 \mathrm{mg} / \mathrm{g})$.

\section{Evaluation the percentage of free radical scavenging capacity in calli cultures}

Radical scavenging capacity (RSC) was evaluated by measuring the scavenging activity of calli extracts on 2,2-diphenyl1-picrylhydrazyl (DPPH) radicals. Gardenia calli extracts involved bioactive substances such as phenols and flavonoids structures as reported previously in Tables 1 and 2 . In this part of our study, calli extracts were examined for their hydrogen donating ability for binding with the DPPH free radical to reduce its stability, changing from purple color to the yellow color according to the antioxidant activity determination. The effect of either PA or SA with their different concentrations in calli culture medium were examined. Their efficacy of discoloration which in turn indicate to their radical scavenging capacity for Gardenia calli at the three harvested periods of culturing were recorded (Table 3). The obtained data revealed that all calli extracts exhibited significantly different antioxidant activity values for reduction DPPH free radical scavenging during the three harvested periods of culturing. The considerable increment in reduction of DPPH was attained with using PA at concentrations 2 and $4 \mathrm{mg} / \mathrm{l}(92.91 \pm 0.87 \%, 82.56 \pm 1.19 \%$, respectively) after 5 weeks of culturing, followed by SA at concentrations 34.5 and $138 \mathrm{mg} / \mathrm{l}$ which recorded lower values $(78.92 \pm$

Table 2 Total flavonoids in gardenia calli cultures cultured on MS media contained different concentrations of phenyl alanine or salicylic acid during the three harvested periods of culturing

\begin{tabular}{|c|c|c|c|}
\hline \multirow[t]{2}{*}{ Treatments } & \multicolumn{3}{|l|}{ Total flavonoids (mg QE/ g DW of callus) } \\
\hline & First harvest (after 2 weeks of culturing) & Second harvest (after 4 weeks of culturing) & Third harvest (after 5 weeks of culturing) \\
\hline Control & $0.181 \pm 0.0027$ & $0.203 \pm 0.0145$ & $0.211 \pm 0.041$ \\
\hline $2 \mathrm{mg} / \mathrm{l}$ phenylalanine & $0.184 \pm 0.038$ & $0.202 \pm 0.033$ & $0.358 \pm 0.002$ \\
\hline $3 \mathrm{mg} / \mathrm{l}$ phenylalanine & $0.191 \pm 0.017$ & $0.207 \pm 0.012$ & $0.212 \pm 0.034$ \\
\hline $4 \mathrm{mg} / \mathrm{l}$ phenylalanine & $0.179 \pm 0.0068$ & $0.226 \pm 0.026$ & $0.225 \pm 0.024$ \\
\hline \multirow[t]{2}{*}{$5 \mathrm{mg} / \mathrm{l}$ phenylalanine } & $0.226 \pm 0.069$ & $0.256 \pm 0.001$ & $0.241 \pm 0.028$ \\
\hline & 69.0747 & & \\
\hline $\begin{array}{l}0.25 \mathrm{mM} \text { salicylic acid } \\
(34.5 \mathrm{mg} / \mathrm{l})\end{array}$ & $0.232 \pm 0.029$ & $0.210 \pm 0.0022$ & $0.226 \pm 0.0172$ \\
\hline $\begin{array}{l}0.5 \mathrm{mM} \text { salicylic acid } \\
(69 \mathrm{mg} / \mathrm{l})\end{array}$ & $0.305 \pm 0.055$ & $0.242 \pm 0.031$ & $0.241 \pm 0.024$ \\
\hline $\begin{array}{l}0.75 \mathrm{mM} \text { salicylic acid } \\
(103.5 \mathrm{mg} / \mathrm{l})\end{array}$ & $0.216 \pm 0.0009$ & $0.225 \pm 0.049$ & $0.227 \pm 0.024$ \\
\hline $\begin{array}{l}1 \mathrm{mM} \text { salicylic acid } \\
(138 \mathrm{mg} / \mathrm{l})\end{array}$ & $0.228 \pm 0.027$ & $0.277 \pm 0.004$ & $0.238 \pm 0.040$ \\
\hline
\end{tabular}

Data represents mean \pm SD 
Table 3 The free radical scavenging capacity percentage in gardenia calli cultures cultured on MS media contained different concentrations of phenyl alanine or salicylic acid during the three harvested periods of culturing

\begin{tabular}{|c|c|c|c|}
\hline \multirow[t]{2}{*}{ Treatments } & \multicolumn{3}{|l|}{ The free radical scavenging capacity $\%$} \\
\hline & First harvest (after 2 weeks of culturing) & Second harvest (after 4 weeks of culturing) & Third harvest (after 5 weeks of culturing \\
\hline Control & $51.72 \pm 0.57$ & $23.18 \pm 1.77$ & $13.21 \pm 1.52$ \\
\hline $2 \mathrm{mg} / \mathrm{l}$ phenylalanine & $37.35 \pm 0.57$ & $44.06 \pm 1.19$ & $92.91 \pm 0.87$ \\
\hline $3 \mathrm{mg} / \mathrm{l}$ phenylalanine & $48.85 \pm 0.57$ & $45.59 \pm 2.39$ & $34.67 \pm 1.84$ \\
\hline $4 \mathrm{mg} / \mathrm{l}$ phenylalanine & $34.09 \pm 0.87$ & $31.80 \pm 0.87$ & $82.56 \pm 1.19$ \\
\hline $5 \mathrm{mg} / \mathrm{l}$ phenylalanine & $24.52 \pm 1.44$ & $48.85 \pm 1.14$ & $49.42 \pm 1.72$ \\
\hline $\begin{array}{l}0.25 \mathrm{mM} \text { salicylic acid } \\
(34.5 \mathrm{mg} / \mathrm{l})\end{array}$ & $41.95 \pm 1.14$ & $36.78 \pm 0.57$ & $78.92 \pm 0.87$ \\
\hline $\begin{array}{l}0.5 \mathrm{mM} \text { salicylic acid } \\
(69 \mathrm{mg} / \mathrm{l})\end{array}$ & $69.73 \pm 0.87$ & $40.99 \pm 1.44$ & $54.98 \pm 1.75$ \\
\hline $\begin{array}{l}0.75 \mathrm{mM} \text { salicylic acid } \\
(103.5 \mathrm{mg} / \mathrm{l})\end{array}$ & $33.52 \pm 1.75$ & $30.07 \pm 1.75$ & $35.82 \pm 1.44$ \\
\hline $\begin{array}{l}1 \mathrm{mM} \text { salicylic acid } \\
(138 \mathrm{mg} / \mathrm{l})\end{array}$ & $71.83 \pm 0.57$ & $10.72 \pm 1.44$ & $55.93 \pm 2.01$ \\
\hline
\end{tabular}

Data represents means \pm SD

$0.87 \%, 71.83 \pm 0.57 \%$, respectively) during 5 and 2 weeks, respectively post-elicitation. From the achieved results, it is observed that the using of either PA or the SA with their different concentrations enhanced more efficiency to reduce free radical DPPH.into the reduced DPPH rather than the control which had performed poorly. Subsequently, it is recommended to add one of them to gardenia calli culture medium particularly PA with $2 \mathrm{mg} / \mathrm{l}$ which is more potent than SA for stimulating the capacity of calli extracts to donate hydrogen atom for enhancement of their antioxidant activity especially at the third harvested period of culturing (after 5 weeks of culturing).

\section{Determination of flavonoids by HPLC}

Data showed in Table 4 revealed that four HPLC flavonoids, rutin, apeginin-7-glucoside, kaempferol, and gentisic, were detected in the different treatments and during three harvested periods of culturing $(2,4$, and 5 weeks of culturing, respectively). Calli cultures harvested after 2 weeks were able to accumulate rutin only, the highest content detected with $69 \mathrm{mg} / \mathrm{l} \mathrm{SA}(202.2 \mu \mathrm{g} / \mathrm{g}$ DW) followed by 3 mg/l PA which gave $(201.0 \mu \mathrm{g} / \mathrm{g}$ DW). After 4 weeks, rutin was not detected with control and $138 \mathrm{mg} / \mathrm{l} \mathrm{S.A.} \mathrm{Moreover,}$ rutin content was decreased at this harvested period of culturing. Calli cultured on $3 \mathrm{mg} / \mathrm{l} \mathrm{PA}$ recorded the highest

Table 4 Flavonoids determination in gardenia calli cultures cultured on MS media contained different concentrations of phenyl alanine or salicylic acid during the three harvested periods of culturing by HPLC

\begin{tabular}{|c|c|c|c|c|c|c|c|c|c|c|c|c|c|c|c|}
\hline \multirow[t]{3}{*}{ Treatments } & \multicolumn{15}{|c|}{ Flavonoids determined in gardenia callus cultures in $\mu \mathrm{g} / \mathrm{g}$ dry weight } \\
\hline & \multicolumn{5}{|c|}{ First harvest (after 2 weeks of culturing) } & \multicolumn{5}{|c|}{ Second harvest (after 4 weeks of culturing) } & \multicolumn{5}{|c|}{ Third harvest (after 5 weeks of culturing } \\
\hline & Rutin & App. & Kaemp. & Gent. & t. $F$ & Ruin & App. & Kaemp. & Gent. & t.f. & Rutin & App. & Kaemp. & Gent. & t.f.. \\
\hline Control & 22.11 & ND & ND & ND. & 22.11 & ND & ND & ND & ND & ND & 20.75 & ND & ND & ND & 20.75 \\
\hline 2 mg/l phenylalanine & 111.3 & ND & ND & ND & 111.3 & 77.56 & ND & ND & ND & 77.56 & 429.8 & 213.16 & 2.993 & ND & 645.95 \\
\hline 3 mg/l phenylalanine & 201.0 & ND & ND & ND & 201.0 & 152.0 & 23.22 & ND & ND & 175.22 & 8.178 & 8.41 & 1.99 & ND & 18.57 \\
\hline 4 mg/l phenylalanine & 20.31 & ND & ND & ND & 20.31 & 50.49 & 5.68 & ND & ND & 56.17 & 137.9 & 31.09 & 4.32 & ND & 173.31 \\
\hline 5 mg/l phenylalanine & 20.76 & ND & ND & ND & 20.76 & 119.57 & ND & 7.18 & ND & 126.75 & 55.91 & 13.73 & 1.66 & ND & 71.3 \\
\hline $\begin{array}{l}0.25 \mathrm{mM} \text { salicylic acid } \\
(34.5 \mathrm{mg} / \mathrm{l})\end{array}$ & 96.44 & ND & ND & ND & 96.44 & 40.82 & ND & 4.90 & ND & 45.72 & 7.05 & 19.52 & 12.47 & ND & 39.04 \\
\hline $\begin{array}{l}0.5 \mathrm{mM} \text { salicylic acid } \\
(69 \mathrm{mg} / \mathrm{l})\end{array}$ & 202.2 & ND & ND & ND & 202.2 & 30.75 & 5.97 & ND & ND & 36.72 & 62.78 & 4.00 & 6.837 & ND & 73.61 \\
\hline $\begin{array}{l}0.75 \mathrm{mM} \text { salicylic acid } \\
(103.5 \mathrm{mg} / \mathrm{l})\end{array}$ & 14.06 & ND & ND & ND & 14.06 & 24.93 & ND & ND & ND & 24.93 & 75.24 & N.D & 3.061 & 3.95 & 82.25 \\
\hline $\begin{array}{l}1 \mathrm{mM} \text { salicylic acid } \\
(138 \mathrm{mg} / \mathrm{l})\end{array}$ & 153.4 & ND & ND & ND & 153.4 & ND & ND & ND & ND & ND & 148.2 & 13.47 & 1.88 & 10.36 & 173.91 \\
\hline
\end{tabular}

ND not detected 
rutin content (152.00 $\mu \mathrm{g} / \mathrm{g} \mathrm{DW})$. Furthermore, apeginin-7glucoside was detected with 3 and $4 \mathrm{mg} / \mathrm{l} \mathrm{PA}$ or $69 \mathrm{mg} / \mathrm{l}$ SA (23.22, 5.68, and $5.97 \mu \mathrm{g} / \mathrm{g}$ DW respectively), whereas kaempferol was detected only with $5 \mathrm{mg} / \mathrm{l}$ PA or $34.5 \mathrm{mg} / \mathrm{l}$ SA (7.18 and $4.90 \mu \mathrm{g} / \mathrm{g}$ Dw, respectively). Interestingly, at the third harvested period of culturing, both rutin and apeginin-7-glucoside recorded their highest content with 3 $\mathrm{mg} / \mathrm{l} \mathrm{PA}$ (429.8 and $213.16 \mu \mathrm{g} / \mathrm{g}$ DW). Also, the same treatment showed the highest total flavonoids contents $(645.95 \mu \mathrm{g} / \mathrm{g} \mathrm{DW})$ among the different treatments and during the different harvested periods of culturing. Kaempferol recorded the highest content with $34.5 \mathrm{mg} / \mathrm{l} \mathrm{SA}$ $(12.47 \mu \mathrm{g} / \mathrm{g} \mathrm{DW})$ at the third harvested period of culturing. Gentisic was detected at this harvested period of culturing (5 weeks) only with 103.5 or $138 \mathrm{mg} / \mathrm{l} \mathrm{SA}$ recording the highest content with $138 \mathrm{mg} / \mathrm{l} \mathrm{SA}(10.36 \mu \mathrm{g} / \mathrm{g} \mathrm{DW})$.

\section{Determination of phenolic compounds by (HPLC)}

Twelve HPLC phenolic compounds, namely cinnamic, rosmarininc, p-hydroxbenzoic, protocatechuic, gallic acid, catechin, caffeic, syringic, $p$-coumaric, vanillic, sinapic, and ferulic, were detected in the different treatments and during the three harvested periods of culturing $(2,4$, and 5 weeks of culturing, respectively) (Tables 5, 6, and 7). Calli cultures harvested after 2 weeks were able to accumulate cinnamic acid as common phenolic compound in all treatment as well as the control one; the highest content was detected with $4 \mathrm{mg} / \mathrm{l} \mathrm{PA}(140.48 \mu \mathrm{g} / \mathrm{g} \mathrm{DW})$ followed by $5 \mathrm{mg} / \mathrm{l}$ PA which gave $(122.96 \mu \mathrm{g} / \mathrm{g}$ DW). The highest accumulation of cinnamic acid in calli treated with SA was recorded with $103.5 \mathrm{mg} / \mathrm{l}$, which gave $(102.1 \mu \mathrm{g} / \mathrm{g}$ DW). Ferulic and rosmarinic acids were also detected in the first harvest. Ferulic acid was detected only with $4 \mathrm{mg} /$ $1 \mathrm{PA}$ or $34.5 \mathrm{mg} / \mathrm{l} \mathrm{SA}(4.87$ and $6.74 \mu \mathrm{g} / \mathrm{g} \mathrm{DW}$, respectively), while rosmarinic acid was detected with control, $3 \mathrm{mg} / \mathrm{l} \mathrm{PA}$ or 34.5 and $69 \mathrm{mg} / \mathrm{l} \mathrm{SA}(96.15,42.01$, 15.45 , and $6.82 \mu \mathrm{g} / \mathrm{g} \mathrm{DW}$, respectively).

At the second harvested period of culturing, it was found that calli cultures were able to accumulate cinnamic acid as common phenolic compound in all treatments recording the highest content with $4 \mathrm{mg} / \mathrm{l} \mathrm{PA}(176.66 \mu \mathrm{g} / \mathrm{g}$ DW) followed by $5 \mathrm{mg} / \mathrm{l}$ PA which gave (133.99 $\mu \mathrm{g} / \mathrm{g}$ DW) taking the same trend as the first harvested period of culturing. While the highest accumulation of cinnamic acid in calli treated with SA was recorded with $34.5 \mathrm{mg} / \mathrm{l}$, which gave $(108.27 \mu \mathrm{g} / \mathrm{g}$ DW). Ferulic and P-hydroxybenzoic acids were detected in calli cultured on SA, recording the highest values with $103.5 \mathrm{mg} / \mathrm{l} \mathrm{SA}(38.24,17.54 \mu \mathrm{g} / \mathrm{g} \mathrm{DW}$, respectively). Calli cultured on PA treatments could not be able to accumulate both phenolic compounds as shown in Table 6 . Interestingly, calli cultures harvested after 5 weeks (third harvested period of culturing) showed high accumulation of phenolic compounds; 11 compounds were detected at this harvested period of culturing, namely cinnamic, rosmarinic, p-hydroxybenzoic, protocatechuic, gallic catechin, caffiec, syringic, P-coumaric, vanillic, and sinapic acids (Table 7). Cinnamic acid was detected as a common phenolic compound in all treatments. The highest cinnamic acid accumulation was recorded with $3 \mathrm{mg} / \mathrm{l} \mathrm{PA}(92.24 \mu \mathrm{g} / \mathrm{g}$ DW), which is lower than that found during the first or the second harvested periods.

\section{Discussion}

\section{Effect of phenyl alanine or salicylic acid on calli growth criteria}

Statistical analysis of variance for the presented data in Figs. 3, 4, and 5 illustrated clearly show that the effect of PA or SA on calli growth during the three harvested

Table 5 Phenolic compound determination in gardenia calli cultures cultured on MS media contained different concentrations of phenyl alanine or salicylic acid during the first harvested period of culturing by HPLC

\begin{tabular}{|c|c|c|c|c|c|}
\hline \multirow[t]{2}{*}{ Treatment } & \multicolumn{4}{|c|}{ Phenolic compounds determined in gardenia callus cultures in $\mu \mathrm{g} / \mathrm{g}$ dry weight in the first harvest } & \multirow[t]{2}{*}{ t. $P$} \\
\hline & Cinnamic & Ferulic & Rosmarinic & Sinapic & \\
\hline Control & 53.75 & ND & 96.15 & ND & 149.9 \\
\hline $2 \mathrm{mg} / \mathrm{l}$ phenylalanine & 73.44 & ND & ND & ND & 73.44 \\
\hline $3 \mathrm{mg} / \mathrm{l}$ phenylalanine & 33.38 & ND & 42.01 & ND & 75.39 \\
\hline 4 mg/l phenylalanine & 140.48 & 4.87 & ND & ND & 145.35 \\
\hline 5 mg/l phenylalanine & 122.96 & ND & ND & ND & 122.96 \\
\hline $\begin{array}{l}0.25 \mathrm{mM} \text { salicylic acid } \\
(34.5 \mathrm{mg} / \mathrm{l})\end{array}$ & 45.59 & 6.74 & 15.45 & ND & 67.78 \\
\hline $\begin{array}{l}0.5 \mathrm{mM} \text { salicylic acid } \\
(69 \mathrm{mg} / \mathrm{l})\end{array}$ & 82.06 & ND & 6.82 & 21.40 & 110.82 \\
\hline $\begin{array}{l}0.75 \mathrm{mM} \text { salicylic acid } \\
(103.5 \mathrm{mg} / \mathrm{l})\end{array}$ & 102.1 & ND & ND & 31.95 & 134.05 \\
\hline $\begin{array}{l}1 \mathrm{mM} \text { salicylic acid } \\
(138 \mathrm{mg} / \mathrm{l})\end{array}$ & 55.97 & ND & ND & 19.15 & 75.12 \\
\hline
\end{tabular}

$N D$ not detected 
Table 6 Phenolic compound determination in gardenia calli cultures cultured on MS media contained different concentrations of phenyl alanine or salicylic acid during the second harvested period of culturing by HPLC

\begin{tabular}{|c|c|c|c|c|}
\hline \multirow[t]{2}{*}{ Treatment } & \multicolumn{3}{|c|}{ Phenolic compounds determined in gardenia callus cultures in $\mu \mathrm{g} / \mathrm{g}$ dry weight in the second harvest } & \multirow[t]{2}{*}{ t. $P$} \\
\hline & Cinnamic & Ferulic & P-hydroxybenzoic & \\
\hline Control & 84.47 & ND & ND & 84.47 \\
\hline $2 \mathrm{mg} / \mathrm{l}$ phenylalanine & 49.40 & ND & ND & 49.40 \\
\hline $3 \mathrm{mg} / \mathrm{l}$ phenylalanine & 61.63 & ND & ND & 61.63 \\
\hline $4 \mathrm{mg} / \mathrm{l}$ phenylalanine & 176.66 & ND & ND & 176.66 \\
\hline 5 mg/l phenylalanine & 133.99 & ND & ND & 133.99 \\
\hline $\begin{array}{l}0.25 \mathrm{mM} \text { salicylic acid } \\
(34.5 \mathrm{mg} / \mathrm{l})\end{array}$ & 108.27 & 14.57 & 8.83 & 131.67 \\
\hline $\begin{array}{l}0.5 \mathrm{mM} \text { salicylic acid } \\
(69 \mathrm{mg} / \mathrm{l})\end{array}$ & 62.76 & 11.25 & ND & 74.01 \\
\hline $\begin{array}{l}0.75 \mathrm{mM} \text { salicylic acid } \\
(103.5 \mathrm{mg} / \mathrm{l})\end{array}$ & 42.24 & 38.24 & 17.54 & 98.02 \\
\hline $\begin{array}{l}1 \mathrm{mM} \text { salicylic acid } \\
(138 \mathrm{mg} / \mathrm{l})\end{array}$ & 50.39 & 32.59 & ND & 82.98 \\
\hline
\end{tabular}

ND not detected

periods of culturing (after 2, 4, and 5 weeks of culturing). Briefly, it could be concluded that the different concentrations of PA or SA increased significantly calli growth parameters compared to the control in the first harvested period of culturing. However, using PA or SA decreased calli fresh weight and growth value and increased both of dry weight and dry matter compared to the control in the second harvested period of culturing. While all treatments increased calli growth parameters compared to the control except the dry matter percentage in the third harvested period of culturing. From the above, it becomes clear the importance of adding elicitors particularly SA in gardenia calli culture medium to increase calli giving the highest amount of calli biomass (fresh weight, dry weight, growth value) after 5 weeks of culturing, which is an indication for more growth, taking in consideration that the control treatment without adding any elicitors or precursor to calli culture medium boosted high yield of calli dry matter percent. Furthermore, it is not preferable adding any elicitors to calli culture medium at the second harvested period of culturing period for less biomass calli productivity, considering their high ratio of dry matter. Additionally, adding elicitors particularly salicylic acid at higher concentrations is more preferable than phenylalanine in gardenia calli culture medium at the first harvested period of culturing for the achievement of cell biomass propagation in calli cultures of Gardenia jasminoides. Data exhibited in Figs. 3, 4, and 5 reported that

Table 7 Phenolic compound determination in gardenia calli cultures cultured on MS media contained different concentrations of phenyl alanine or salicylic acid during the third harvested period of culturing by HPLC

\begin{tabular}{|c|c|c|c|c|c|c|c|c|c|c|c|c|}
\hline \multirow[t]{2}{*}{ Treatment } & \multicolumn{11}{|c|}{ Phenolic compounds determined in gardenia callus cultures in $\mu \mathrm{g} / \mathrm{g}$ dry weight in the third harvest } & \multirow[t]{2}{*}{ t. $P$} \\
\hline & Cinnamic & Rosmarinic & $\begin{array}{l}\text { P- } \\
\text { hydroxy }\end{array}$ & Protocatechuic & Gallic & Catechin & Caffeic & Syringic & $\begin{array}{l}\mathrm{p}- \\
\text { coumaric }\end{array}$ & Vanillic & Sinapic & \\
\hline Control & 79.95 & ND & N.D. & 128.177 & 85.13 & N.D. & N.D. & N.D. & N.D. & N.D. & N.D. & 293.25 \\
\hline $2 \mathrm{mg} / \mathrm{l}$ phenylalanine & 49.87 & 213.16 & 18.76 & 14.2414 & ND & 297.23 & 7.14 & 30.71 & 43.47 & 4.86 & 9.0074 & 688.44 \\
\hline $3 \mathrm{mg} / \mathrm{l}$ phenylalanine & 92.24 & ND & ND & ND & ND & ND & ND & ND & 5.21 & ND & ND & 97.45 \\
\hline $4 \mathrm{mg} / \mathrm{l}$ phenylalanine & 49.36 & 40.26 & 19.13 & ND & ND & 54.72 & ND & 9.51 & 1.97 & ND & ND & 174.95 \\
\hline $5 \mathrm{mg} / \mathrm{l}$ phenylalanine & 68.997 & 15.52 & 10.32 & ND & ND & 40.28 & ND & ND & 5.094 & ND & ND & 140.21 \\
\hline $\begin{array}{l}0.25 \mathrm{mM} \text { salicylic acid } \\
(34.5 \mathrm{mg} / \mathrm{l})\end{array}$ & 52.48 & 19.72 & ND & ND & ND & 138.59 & 5.35 & 105.9 & 14.87 & 68.23 & ND & 405.14 \\
\hline $\begin{array}{l}0.5 \mathrm{mM} \text { salicylic acid } \\
(69 \mathrm{mg} / \mathrm{l})\end{array}$ & 72.37 & 22.48 & 5.21 & ND & ND & 180.80 & ND & 2.35 & 20.975 & ND & 5.4139 & 309.59 \\
\hline $\begin{array}{l}0.75 \mathrm{mM} \text { salicylic acid } \\
(103.5 \mathrm{mg} / \mathrm{l})\end{array}$ & ND & 24.06 & 45.46 & ND & ND & 246.65 & ND & ND & 41.45 & ND & 8.24 & 365.86 \\
\hline $\begin{array}{l}1 \mathrm{mM} \text { salicylic acid } \\
\text { (138 mg/l) }\end{array}$ & 49.65 & 78.20 & 11.40 & ND & ND & 493.65 & 5.105 & 3.07 & 2.55 & ND & 6.12 & 649.74 \\
\hline
\end{tabular}

ND not detected 
adding PA or SA to the culture medium especially SA at $138 \mathrm{mg} / \mathrm{l}$ increase calli cultures biomass, while the high concentrations of both of PA and SA reduced partially the calli cultures' biomass criteria. Our findings are in agreement slightly with those of (El-Nabarawy et al., 2015) who revealed that higher concentrations of phenylalanine inhibited the fresh weight of Zingiber officinale calli in comparison with the fewer levels, Bemani et al. (2012) who found that up to $3 \mathrm{mM}$ of PA affected adversely hazel cells growth of Corylus avellana L. and at $6 \mathrm{mM}$ of PA had no significant influence on cells dry weight and Bosila et al. (2012) who confirmed the significant differences for calli dry weight according to the amino acid or precursor levels, where expanding the concentrations of PA (100 and 200 $\mathrm{mg} / \mathrm{l}$ ) decreased calli dry weight of Silybum marianum L. In this study, it was found that SA had positive capacity and good response rather than PA for high performance of gardenia calli growth. This achievement is in line with various earlier studies such as Lingakumar et al. (2014) who initiated calli of Vigna mungo on MS medium containing $0.5 \mathrm{ppm}$ SA then induced high percentage of callus induction frequency using $1 \mathrm{ppm}$ SA, Quiroz-Figueroa and Mendez-Zeel (2001) who reported that SA is a hormone like chemical which enhance in vitro regeneration for plenty of plant species including Coffea arabica, and (Hao et al., 2006) who increased calli dry weight of naked oat using SA. This positive effect of SA on calli proliferation due to both of ethylene production increment in the atmosphere of calli which perhaps is responsible for their growth and maturation enhancement and the acceleration processes conducted with the cell division. Sakhanokho and Kelley (2009) who revealed that the positive effect of SA on plant tissue culture propagation may be a reflection of an increase in the meristematic number, where SA acts as morphoregulator signal to support the assumption that SA is a growth regulator. Our obtained results about the significant role of SA on calli match with those of Galal (2012) who confirmed that the exogenous addition of SA in culture media affected positively calli, shoot, and root propagation of Ziziphus spina-christi.

\section{Biochemical analysis}

\section{Determination of total phenols in calli culture}

Based on the previous investigations (Table 1), it is recommended to add PA in gardenia calli culture medium for enhancement phenols production. Our results are matching with the earliest studies by Riedel et al. (2012) who reported that the increment of phenolic synthesis in cultures of Vitis vinifera are with using $0.1 \mathrm{mM}$ of PA as precursor and Razzaque and Ellis (1977) who discovered that the plant tissue is in need of PA to stimulate the phenylalanine ammonia lyase (PAL) activity which is a portal of shikimic acid pathway for phenols production. With regard to our obtained results about the inhibitory effectiveness for SA-treated calli cultures at all harvested periods of culturing with respect to phenols production. This investigation is in accordance with the earlier studies by Gadzovska et al. (2013) who revealed that the cells of Hypericum perforatum L. elicitated with SA had lower effect than jasmonic acid (JA) elicitation on phenyl propanoids contents, where phenols content is stable or less in SA-elicited shoots than in the corresponding controls which in turn lead to secondary metabolites reduction comparable with the control. Goyal and Ramawat (2008) confirmed that methyl jasmonate (MeJA) at concentration $20 \mu \mathrm{M}$ was more effective than SA in isoflavonoid production in Pueraria tuberose cell cultures.

\section{Determination of total flavonoids in calli cultures}

The substantial result from the achieved data in Table 2 revealed the fact that MS medium elicited by SA increased the total flavonoids content in gardenia cultures more than MS medium fortified with PA at first and second harvested periods of culturing, excluding $2 \mathrm{mg} / \mathrm{l} \mathrm{PA}$ with respect to the third harvested period of culturing. Upon the positive influence of SA concentrations on flavonoids production from Gardenia calli cultures during three harvested period of culturing post-elicitation, it is recommended to add SA particularly at concentration $69 \mathrm{mg} / \mathrm{l}$ in Gardenia calli culture medium for 2 weeks of culturing. These results are partially in parallel with Gadzovska et al. (2013) who observed the increment of flavonols (7-21 days) and flavanols (1-4 days) between two- to fivefold in calli of Hypericum perforatum $L$. with the presence of SA particularly by using their lower concentrations. Salicylic acid has a great role in the regulation of plant development and growth as hormone-like substance (Kang et al., 2006) where SA induces gene regulation associated to the secondary metabolites biosynthesis (Taguchi et al., 2001) and affect diversely on the plant physiological processes (Malabadi et al., 2008a; Malabadi et al., 2008b).

In general, our obtained results in Tables 1 and 2 indicated to the potent efficacy of both PA and SA for enhancement of the total content of phenols and flavonoids accumulation in gardenia callus cultures during three harvested periods of culturing. Most of phenols production was accentuated on gardenia cell cultures using all PA concentrations comparable with SA particularly after 5 weeks of elicitation. This reverse in respect of flavonoids production which was highly accumulated on Gardenia calli cultures using SA compared to PA at all the three harvested periods of culturing. Subsequently, it could be concluded that either PA or SA are preferable and have been recommended in calli culture medium of Gardenia jasminoides for boosting and enhancing their productivity of phenols and flavonoids content. This obtained investigation from our study was confirmed by Gabr et al. (2017) who verified little amounts of both of phenols and 
flavonoids content in gardenia calli grown on MS medium non-elicited by any elicitors or stimulator compounds.

PA as amino acid accelerates primer metabolism operation during phosphor enol pyruvic acid conversion to pyruvic acid; this acid act as key compound in several biochemical pathways (Noviyanti et al., 2017); PA as aromatic amino acid possess function as bio block of protein and has an effect on hormone synthesis such as salicylate and auxin (Tzin \& Galili, 2010).

\section{Evaluation the percentage of free radical scavenging capacity in calli cultures}

Our findings (Table 3 ) are in line with the results reported earlier by Arafa et al. (2015) and Arafa and Aly (2018), who detected that the highest scavenging activity values in calli of stem, root, and petiole explants of Daucua carota L. carota was recorded with using phenylalanine as amino acid precursor and Bemani et al. (2012) who increased more amounts of Taxol and antioxidant activity by increment of phenylalanine supply in the extract of suspension-cultured hazel (Corylus avellana L.) cells. Furthermore, our investigations are in partial harmony with those of Ghasemzadeh et al. (2012) who reported that SA improved the production of some chemical structures such as fisetin and anthocyanin who possess more potency as antioxidant activity than the control in ginger varieties and Hadian-Deljou et al. (2017) who attained more total phenolics and antioxidant activity by salicylic acid application using $2 \mathrm{mM}$ concentration at the earlier stages of cold storage and using $1 \mathrm{mM}$ concentration at the end of cold storage for red delicious apples.

\section{Determination of flavonoids by HPLC}

Rutin is found to be functional as an activator to improve plant disease resistances to bacterial pathogens via rutin-priming defense signal which is modulated by the salicylic acid-dependent pathway (Wei et al., 2016). Our previous work (Gabr et al., 2017) recorded that calli cultures of gardenia (Gardenia jasminoides) on $4 \mathrm{mg} / \mathrm{l} \mathrm{TDZ}$ produced 287.76 and $10.38 \mu \mathrm{g} / \mathrm{g}$ of rutin and kaempferol, respectively. And, apeginin-7-glucoside was detected with high content $(129.86 \mu \mathrm{g} / \mathrm{g})$ in callus culture with $4 \mathrm{mg} / \mathrm{l}$ Zeatin. PA is a vital component of proteins in all living organisms, and in plants is a precursor for thousands of additional metabolites. In addition to structural roles, phenylalanine-derived compounds function in plant defense and ultraviolet protection (for example, flavonoids and various phenolics) (Yoo et al., 2013).

\section{Determination of phenolic compounds by HPLC}

Cinnamic acid was detected as a common phenolic compound in all treatments. In this respect, Kovácik et al. (2007) reported that cinnamic acid is considered as the first metabolite of the phenyl propanoid pathway and the precursor for flavonoids pathway. In the present study, several phenolic compounds (rosmarinic, p-hydroxy, caffeic acid, syringic p-coumaric sinapic and catechin) were detected in calli culture feeding with phenyl alanine and salicylic acid and were not detected in control treatment. Gabr et al. (2016) reported that the highest accumulation of cinnamic acid was recorded with control treatment compared with elicited callus culture in milk thistle. The role of salicylic acid in the regulation immune defenses has become clearer (Gawronski et al., 2013). SA increases the accumulation of both ABA and IAA in plant seedlings under salt stress. However, the SA treatment did not affect the cytokinin content. So, the SA protective action in plant cells includes the development of anti-stress system and promotes the normalization of growth after removal of stress factors (Sakhabutdinova et al., 2003).

\section{Conclusion}

Rutin and cinnamic acid are the major compounds detected in all treatments and during the three harvested periods of culturing for calli cultures of gardenia. Our results declared that the decreasing in cinnamic acid is correlated with the increasing of rutin content. A further study is required to evaluate the effect of different biotic or abiotic elicitor on regulation of phenolic and flavonoid accumulation in in vitro culture of gardenia.

\section{Abbreviation \\ PA: Phenylalanine; SA: Salicylic acid; MeJA: Methyl jasmonate}

\section{Acknowledgement}

Fund was provided by the National Research Centre (Grant number: AR11110).

\section{Author's contribution}

AAE and AMMG conceived and designed the experiments; AAE performed the experiments; $A A E, A M M G$, and NMA analyzed the data; MKE and NMA wrote the paper. All authors edited the final manuscript. All authors read and approved the final manuscript.

\section{Funding}

Fund was provided by the National Research Centre (Grant number: AR11110).

Availability of data and materials

All relevant data generated during this study are within the paper and its additional information files.

Ethics approval and consent to participate

Approved.

Consent for publication

Applicable.

Competing interests

The authors declare that they have no competing interests.

Received: 3 July 2019 Accepted: 5 August 2019

Published online: 30 August 2019

\section{References}

Arafa NM, Aly UI (2018) In-vitro radical scavenging activity of Daucuscarota L. extracts. Egyptian Pharmaceutical Journal 17:48-52 
Arafa NM, Ibrahim MM, Aly UI (2015) Evaluation of total phenolic contents and antioxidant activity of carrot callus extracts as affected by phenylalanine precursor. Plant Tissue Cult \& Biotech 25(2):207-221

Bektas Y, Eulgem T (2015) Synthetic plant defense elicitors. Front Plant Sci 5:803-804

Bemani E, Ghanati F, Rezaei A, Jamshidi M (2012) Effect of phenylalanine on Taxol production and antioxidant activity of extracts of suspension-cultured hazel (Corylusavellana L.) cells. J Nat Med. https://doi.org/10.1007/s11418012-0696-1

Bosila H, Toiama N, Al-Ameir H, El Ateeq A (2012) Effect of some amino acids, precursors, and light conditions on callus growth and silymarin content of Silybummarianum L.Al-Azhar. J Agric Res 12:85-104

Dharmananda S (2003). Gardenia: Key herb for dispelling dampness and heat via the triple burner, Inistitute for Traditional Medicine, Portland, Oregon. http:// www.itmonline.org/arts/gardenia.htm

Duraipandiyan V, Ayyanar M, Ignacimuthu S (2006). BMC Complement Alt Med, 635-640.

El-Nabarawy MA, El-Kafafi SH, Hamza MA, Omar MA (2015) The effect of some factors on stimulating the growth and production of active substances in Zingiberofficinale callus cultures. Ann Agric Sci:1-8

Gabr AMM, Arafa NM, El Ashry AA, El Bahr MK (2017) Impact of zeatin and thidiazuron on phenols and flavonoids accumulation in callus cultures of Gardenia (Gardenia jasminoides). Pak J Biol Sci 20(7):328-335

Gabr AMM, Ghareeb H, El Shabrawi HM (2016) Enhancement of silymarin and phenolic compound accumulation in tissue culture of Milk thistle using elicitor feeding and hairy root cultures. Genet Eng Biotechnol J 14(2)

Gabr AMM, Mabrok HB, Abdel-Rahim EA, El-Bahr MK, Smetanska I (2018) Determinaion of lignans, phenolic acids and antioxidant capacity in transformed hairy root culture in Linumusitatissimum. Nat Prod Res 32(15): 1867-1871

Gadzovska S, Maury SF, Delaunay A, Spasenoski M (2013) The influence of salicylic acid elicitation of shoots, callus, and cell suspension cultures on production of naphtodianthrones and phenylpropanoids in Hypericumperforatum L. Plant Cell Tissue Organ Cult 113:25-39

Galal A (2012) Improving effect of salicylic acid on the multipurpose tree Ziziphusspina-christi (L.) wild tissue culture. Am J Plant Sci 3:947-952

Ganeshpurkar A, Saluja AK (2017) The pharmacological potential of Rutin. Saudi Pharm J 25(2):149-164

Gawronski P, Górecka M, Bederska M, Rusaczonek A, Slesak I, Kruk J (2013) Isochorismate synthase 1 is required for thylakoid organization, optimal plastoquinone redox status, and state transitions in Arabidopsis thaliana. J Exp Bot 64:3669-3679. https://doi.org/10.1093/jxb/ert203

Ghasemzadeh A, Jaafar HZE, Karimi E (2012) Involvement of salicylic acid on antioxidant and anticancer properties, anthocyanin production and chalcone synthase activity in Ginger (Zingiberofficinale Roscoe) varieties. Int J Mol Sci 13:14828-14844

Goyal S, Ramawat KG (2008) Increased isoflavonoid accumulation in cell suspension cultures of Pueraria tuberose byelicitors. Indian J Biotechnol 7: 378-382

Habtemariam S (2019) Antioxidant and rutin content analysis of leaves of the Common Buckwheat (FagopyrumesculentumMoench) grown in the United Kingdom: A case study. Antioxidants 8(6):160. https://doi.org/10.3390/ antiox8060160

Hadian-Deljou M, Esna-Ashari M, Sarikhani H (2017) Effect of pre- and postharvest salicylic acid treatments on quality and antioxidant properties of 'Red Delicious' apples during cold storage. Adv Hortic Sci 31(1):31-38

Hao L, Zhou L, Xu X, Cao J, Xi T (2006) The role of salicylic acid and carrot embryogenic callus extracts in somatic embryogenesis of naked Oat (Avenanuda). Plant Cell Tissue Organ Cult 85(1):109-113

Javed H, Khan MM, Ahmad A, Vaibhav K, Ahmad ME, Khan A, Ashafaq M, Islam F, Siddiqui MS, Safhi MM (2012) Rutin prevents cognitive impairments by ameliorating oxidative stress and neuroinflammation in rat model of sporadic dementia of Alzheimer type. Neuroscience. 17: 340-352

Kang S, Kim HL, Le H, Choi JY, Heu H, Oh CJ (2006) Over expression of Arabidopsis of a plasma membrane-targeting glutamate receptor from small radish increases glutamate-mediated $\mathrm{Ca}+2$ influx and delays fungal infection. Mol Cell 21(3):418-427

Kovácik J, Klejdus B, Backor M, Repcak M (2007) Phenylalanine ammonialyase activity and phenolic compounds accumulation in nitrogendeficient Matricariachamomilla leaf rosettes. Plant Sci 172:393-399
Lingakumar K, Asha A, Vairamathi SP (2014) Comparative effects of auxins, jasmonic acid and salicylic acid on call initiation and organogenesis in Vignamungo (L.) Hepper using hypocotyl explant. J of Stress Physiology and Biochemistry 10(1):262-267

Malabadi RB, Teixeira da Silva J, Nataraja K (2008a) A new approach involving salicylic acid and thin cell layers for cloning mature trees of Pinusroxburghii (Chir Pine). The American J Plant Sci and Biotech 2(2):56-59

Malabadi RB, Teixeira da Silva J, Nataraja K (2008b) Salicylic acid induces somatic embryogenesis from mature trees of Pinusroxburghii (Chir pine) using TCL Technology. Tree and Forestry Science and Biotechnology 2(1):34-39

Mizukam H (1989). XII Gardenia jasminoidesEllis: In vitro propagation and the formation of iridoidglucosides. In: Biotechnology in Agriculture and Forestry, Vol. 7 Medicinal and Aromatic Plants II (ed. by Y. P. s. Bajaj). Springer-Verlag Berlin Heidelberg.

Noviyanti R, Sari RLK, Kristanti AN, ArifYachya A, Yosephine S, WulanManuhara YSW (2017) Biomass and flavonoid production of Gynuraprocumbens adventitious roots induced by sucrose, phenylalanine and tyrosine. Biosci Res 14(4):934-941

Ordon JD, Gomez MA, Vattuone MI (2006) Antioxidant activities of Sechiumedule (Jacq.) Swartz extracts. Food Chem 97:452-458

Rothwell JA, Medina-Remón A, Perez-Jimenez J, Neveu V, Knaze V, Slimani N, Scalbert A. (2015) Effects of food processing on polyphenol contents: A systematic analysis using phenol-explorer data. Molecular Nutrition \& Food Research, 59, 160-170.

Quiroz-Figueroa F, Mendez-Zeel M (2001) Picomolar concentration of salicylates induce cellular growth and enhance somatic embryogenesis in Coffeaarabica tissue culture. Plant Cell Rep 20:679-689

Rao SR, Ravishankar GA (2000) Vanilla flavor: production by conventional and biotechnological routes. J Sci Food Agric 80(3):289-304

Razzaque A, Ellis BE (1977) Rosmarinic acid production in Coleus cell cultures. Planta 137:287-291

Richetti SK, Blank M, Capiotti KM, Piato AL, Bogo MR, Vianna MR, Bonan CD (2011) Quercetin and rutin prevent scopolamine-induced memory impairment in zebrafish. Behav Brain Res 217:10-15

Riedel H, Akumo DN, Nay MMTS, Kutuk O, Neubauer P, Smetanska I (2012) Licitation and precursor feeding influence phenolic acids composition in Vitisvinifera suspension culture. Afr J Biotechnol 11(12):3000-3008

Saeedeh A, Asna U (2007) Antioxidant properties of various solvent extracts of mulberry (Morusindica L.) leaves. Food Chem 102:1233-1240

Sakhabutdinova AR, Fatkutdinova D, Bezrukova MV, Shakirova FM (2003) Salicylic acid prevents the damaging action of stress factors on wheat plants. Bulg J Plant Physiology, Special Issue 21:314-319

Sakhanokho HF, Kelley RY (2009) Influence of sali-cylic acid on in vitro propagation and salt tolerance in Hibiscus acetosella and Hibiscus moscheutos (cv 'Luna Red'). Afr J Biotechnol 8(8):1474-1481

Sathuluri RR, Ravishankar G (2000) Vanilla flavour: Production by conventional and biotechnological routes. J Sci Food Agric 80(3):289-304

Slinkard K, Singleton VL (1997) Total phenol analyses: automation and comparison with manual methods. Am J EnolVitic 28:49-55

Taguchi G, Yazawa T, Hayashida N, Okazaki M (2001) Molecular cloning and heterologous expression of novel glucosyltransferases from tobacco cultured cells that have broad substrate specificity and are induced by salicylic acid and auxin. Eur J Biochem 268:4086-4094

Tzin V ,Galili G (2010). The biosynthetic pathways for shikimate and aromatic amino acids in Arabidopsis thaliana. The Arabidopsis Book, . 8: 130-132. Published online 2010 May 17.

Uddin R, Saha M R, Subhan N, Hossain H, Jahan IA, Akter R, Alam A (2014). Advanced pharmaceutical bulletin. , 4(3), 273-281

Van-Calsteren MR, Bissonnette MC, Cormier F (1997) Spectroscopic characterization of crocetin derivatives from Crocus sativus and Gardenia jasminoides. J Agric Food Chem 45:1055-1061, 1997

Wei Y, Xiaonan X, Yang L, Yingzi W, Ming L, Yong W, Xinhua D, Zhaohui C (2016) Rutin-mediated priming of plant resistance to three bacterial pathogens initiating the early SA signal pathway. PLOS ONE. | DOI: https://doi.org/10.13 71/journal.pone.0146910

Yoo H, Widhalm JR., Qian Y, Maeda H, Cooper BR, Jannasch AS, Gonda I, Lewinsohn E, Rhodes D, NDudareva N (2013). An alternative pathway contributes to phenylalanine biosynthesis in plants via a cytosolic tyrosine: phenylpyruvate aminotransferase. Nat Commun. | 4:2833 | DOl: https://doi. org/10.1038/ncomms3833 
Zhao J, Davis LC, Verpoorte R (2005) Elicitor signal transduction leading to production of plant secondary metabolites. Biotechnol Adv 23(4):283-333

\section{Publisher's Note}

Springer Nature remains neutral with regard to jurisdictional claims in published maps and institutional affiliations.

Submit your manuscript to a SpringerOpen ${ }^{\circ}$ journal and benefit from:

- Convenient online submission

- Rigorous peer review

- Open access: articles freely available online

- High visibility within the field

- Retaining the copyright to your article

Submit your next manuscript at $\boldsymbol{\wedge}$ springeropen.com 